\title{
Isu-isu Riset Ilmu Kebumian Terkini di Kawasan Karst
}

\section{Ahmad Cahyadi}

Departemen Geografi Lingkungan, Fakultas Geografi, Universitas Gadjah Mada

Yogyakarta

\section{Intisari}

Isu tentang perubahan iklim kini telah menjadi perhatian dunia, tidak terkecuali para ahli kebumian di kawasan karst. Kawasan karst diyakini akan memiliki peranan besar dalam menghadapi perubahan iklim, terutama terkait dengan penyediaan sumberdaya air serta penyerapan karbodioksida atmosfer. Beberapa isu menarik terkait dengan isu riset kebumian dipaparkan dalam makalah ini. Diharapkan makalah ini dapat membangkitkan semangat penelitian ilmu-ilmu kebumian di kawasan karst, sehingga kawasan karst di masa mendatang dapat memberikan manfaat sebanyak-banyaknya dengan tanpa menghilangkan keberlanjutan fungsinya.

Kata Kunci: Karst, Isu Riset Terkini, Ilmu Kebumian

\section{Pendahuluan}

Semakin meningkatnya gaung isu dampak perubahan iklim sejak pertama kali digaungkan pada tahun 1992 pada Konferensi Tingkat Tinggi (KTT) Persatuan Bangsa Bangsa (PBB) di Rio de Jenairo, Brazil menyebabkan isu terkait dengan kawasan karst ikut terangkat menjadi semakin nyata. Kawasan karst diperkirakan akan menjadi ekosistem yang memegang peranan yang penting dalam upaya-upaya mitigasi dampak perubahan iklim (Cheng, 2011; Zhen et.al., 2011; Junbing dan Qian, 2012). Peran kawasan karst utamanya terkait dengan sumberdaya air yang melimpah serta penyerapan karbondioksida atmosfer melalui proses pelarutan batuan karbonat dan simpanan karbon terbanyak dibandingkan penyimpan yang lain di Bumi, di mana simpanan karbon di kawasan karst berbentuk padatan dalam batuan.

Kawasan karst merupakan kawasan yang dibentuk oleh adanya interaksi antara air dan batuan yang menyebabkan terjadinya proses pelarutan dan akhirnya memebentuk karakteristik bentanglahan yang khas berupa kondisi hidrologi yang sangat dipengaruhi oleh perkembangan 
pelorongan hasil proses pelarutan (Cahyadi, 2010; Cahyadi, 2014a). Leibundgut et.al. (1998) menyebutkan bahwa kawasan karst adalah sistem hidrogeologi dan geomorfologi yang terbentuk oleh pelarutan batuan oleh air meteorik yang lebih besar dari pelarutan yang normal. Perautan yang besar tersebut disebabkan adanya batuan yang mudah larut seperti batuan karbonat. Karst secara luas terdapat di permukaan Bumi dengan luas diperkirakan sekitar 20\% dari luas daratan di permukaan Bumi (White et.al., 1993) sampai dengan $30 \%$ (William, 1993). Kawasan karst terluas di dunia berada di Tiongkok bagian selatan, yakni dengan luas $900.000 \mathrm{~km}^{2}$ (Leibundgut et.al., 1998).

\section{Kawasan Karst Sebagai Sumber Air}

Pembentukan lapisan epikarst di bagian atas dari kawasan karst menjadi kunci penyimpanan air. Retakan-retakan (diaklas) yang terbetuk di bagian atas kawasan karst serta lorong-lorong pelarutan yang berkembang akan menyebabkan air hujan yang berubah menjadi airtanah menjadi sangat besar (Radulovic et.al., 2012). Aliran-aliran diffuse (aliran antar butir) akan mengontrol pengatusan air dalam lapisan epikarst menuju ke sungai bawah tanah dan mataair secara perlahan, sehingga air akan tetap tersedia di musim kamarau.

Meskipun hanya menyusun sekitar 20\% - 30\% luas permukaan Bumi, kawasan karst selama dua dekade terakhir diperkirakan telah berperan dalam penyediaan sekitar seperempat kebutuhan air bersih di seluruh dunia (Ford dan William, 2007; Ravbar, 2007). Kota-kota besar di Eropa seperti London, Bristol, Paris, Montpellier, Wina dan Roma merupakan contoh kota yang memenuhi kebutuhan air bersihnya dari sumberdaya air di kawasan karst (Andreo, 2012). Selain itu, banyak pula negara yang sangat bergantung terhadap kawasan karst dalam pemenuhan kebutuhan air bersihnya, misalnya Austria dan Slovenia yang mencukupi sekitar separuh kebutuhan air bersihnya dari akuifer kawasan karst. Forti (2002) menyebutkan bahwa para ahli memperkirakan pada tahun 2025 sekitar $80 \%$ kebutuhan air bersih di seluruh dunia akan dipenuhi dari akuifer di kawasan karst.

\section{Kawasan Karst Sebagai Ekosistem yang Rapuh}

Selain memiliki sumberdaya air yang melimpah di bagian akuifernya, kawasan karst juga memiliki sifat yang mudah rusak. Pengelolaan lingkungan yang salah di kawasan ini akan menyebabkan pemulihan ekosistem sulit dilakukan. Selain itu, proses pelarutan yang membentuk 
lorong-lorong akan menyebabkan kerentanan airtanah terhadap pencemaran menjadi tinggi (Cahyadi dkk., 2013a).

Tanah yang tipis di kawasan karst akan menyebabkan air akan segera meresap ke sistem sungai bawah tanah dengan sedikit/tanpa proses penyaringan oleh tanah. Hal ini berarti kontaminan yang dapat menyebabkan pencemaran airtanah akan sangat mudah masuk ke dalam sistem sungai bawah tanah. Selain itu, adanya sistem alogenik yang memiliki tangkapan air di daerah permukaan menyebabkan mudahnya kativitas manusia mempengaruhi kualitas airtanah di kawasan karst.

Contoh kerusakan ekosistem kawasan karst yang sulit dipulihkan adalah adanya perambahan hutan/ penambangan gamping pada perbukitan yang menyebabkan kerusakan lahan. Perambahan hutan dan penambangan batu gamping menyebabkan terjadinya erosi yang tinggi sehingga menyebabkan tanah menjadi sangat tipis dan kemudian menyebabkan lahan mengalami penggurunan (rocky desertification). Selain itu, kerusakan lahan juga menyebabkan dangkalnya telaga-telaga di bagian bawah perbukitan, sehingga tidak dapat lagi menampung air hujan (air akan lebih banyak mengalami penguapan). Kerusakan lahan seperti yang dijelaskan sebelumnya akan sulit untuk dikembalikan kondisinya mengingat pembentukan tanah di kawasan karst membutuhkan waktu yang sangat lama (Cahyadi, 2014b). Selain itu, pendangkalan telaga juga sulit diatasi mengingat kesalahan dalam pengerukan telaga justru akan menyebabkan kebocoran telaga sehingga tidak mampu lagi menampung air.

\section{Isu-isu Terkini Riset IImu Kebumian di Kawasan Karst}

Junbing dan Qian (2012) menyebutkan bahwa setidaknya terdapat empat isu-isu terkini terkait dengan penelitian ilmu kebumian di kawasan karst. Kedua penulis menyebutkan isu-isu tersebut meliputi:

1. Potensi penyerapan karbon dan kaitannya dengan perubahan iklim;

2. Sistem akuifer dan sumberdaya air di kawasan karst;

3. Perlindungan daerah tangkapan air kawasan karst yang berkelanjutan; dan

4. Catatan perubahan lingkungan di kawasan karst.

Bahasan terkait dengan potensi penyerapan karbon di kawasan karst selain menyoroti terkait dengan potensi penyimpanan karbon dalam tanah dan batuan di kawasan karst (Cahyadi dan Priadmodjo, 2012), bahasan ini juga menyoroti tentang peranan vegetasi dan mikroorganisme dalam membantu penyerapan karbondioksida atmosfer. Selain itu, bahasan ini juga menyoroti siklus hidrogeokimia dalam sistem karst dinamik. 
Bahasan terkait dengan sistem akuifer dan sumberdaya air di kawasan karst utama terkait dengan karakterisasi akuifer karst dengan analisis hidrologi dan hidrogeokimia dan analisis ketersediaan air. Analisis ini sangat penting mengingat kawasan karst berperan besar dalam pemenuhan kebutuhan air bersih. Analisis terkait dengan karakteristik akuifer akan memudahkan dalam manajemen dan perencanaan pemanfaatan airtanah di kawasan karst.

Bahasan terkait dengan perlindungan daerah tangkapan air kawasan karst yang berkelanjutan menyoroti tentang perlindungan bagian permukaan dari kawasan karst dalam rangka perlindungan sumberdaya lahan dan air (Cahyadi dkk., 2012a; Cahyadi dkk., 2013b; . Kajian terkait bahasan ini terkait dengan pemanfaatan lahan seperti permukiman, pertambangan, industri dan pertanian, kajian terkait dengan pemetaan kerentanan pencemaran (Cahyadi dan Hartoyo, 2011; Cahyadi dkk., 2012b) dan sumber pencemar, serta kajian mengenai estimasi imbuhan airtanah. Kajian ini sangat penting demi terjaganya ekosistem permukaan kawasan karst serta terjaganya air permukaan (telaga) dana airtanah di kawasan karst.

Bahasan tentang catatan perubahan lingkungan di kawasan karst fokus menyoroti tentang jejak-jejak dari perubahan lingkungan yang terekam melalui berbagai proxy iklim, misalnya endapan gua, lapisan stalagmit, bentuk lorong gua, struktur geologi, sistem sungai bawah tanah yang terbentuk serta bentukan-bentukan pada ornamen gua. Kajian ini bermanfaat untuk mengetahui dampak perubahan lingkungan di masa lampau dan dampaknya terhadap kawasan karst, sehingga dapat disusun sebuah langkah-langkah mitigasi terhadap kemungkinan perubahan lingkungan dimasa mendatang.

\section{Penutup}

Isu-isu terkait dengan kajian ilmu kebumian di kawasan karst sebenarnya sangat luas. Namun demikian, tentunya dibutuhkan prioritas. Kajian terkait ekosistem kawasan karst pun tentunya tidak akan banyak bermanfaat ketika tidak dilakukan secara holistik dengan berkolaborasi dengan keilmuan yang lain. Kawasan karst adalah kawasan yang memiliki peran ekologi yang besar bagi kehidupan makhluk hidup di Bumi termasuk manusia, dan diperkirakan akan semakin penting seiring dengan fenomena perubahan iklim. Namun demikian di sisi yang lain ekosistem karst adalah ekosistem yang rentan dan rapuh, sehingga pemanfaatannya harus dilakukan dengan pertimbangan yang matang. Hal ini mengingat 
pengembalian pada kondisi setelah mengalami kerusakan akan sangat sulit dilakukan.

\section{Pengakuan}

Makalah ini merupakan bagian dari hibah Penelitian Unggulan Perguruan Tinggi (PUPT) Kementerian Riset, Teknologi dan Pendidikan Tinggi (Kemenristekdikti) tahun 2016 yang berjudul "Karakterisasi Hidrologi dan Banjir di Sungai Bawah Tanah Goa Pindul untuk Pengelolaan Pariwisata Berkelanjutan Berbasis Manajemen Kebencanaan" dengan nomor kontrak 679/UN1-P.III/LT/DIT-LIT/2016.

\section{Daftar Pustaka}

Andreo, B. 2012. Introductory Editorial: Advances in Karst Hydrogeology. Environmental Earth Sciences, 65: 2219 - 2220.

Cheng, Z. 2011. Carbonate Rock Dissolution Rates in Different Landuse and Their Carbon Sink Effect. Chinese Science Bulletin, 56: 3759 3765.

Cahyadi, A. 2010. Pengelolaan Kawasan Karst dan Peranannya dalam Siklus Karbon di Indonesia. Prosiding Seminar Nasional Perubahan Iklim. Yogyakarta: Sekolah Pascasarjana Universitas Gadjah Mada.

Cahyadi, A. dan Hartoyo, F.A. 2011.Pemanfatan Sistem Informasi Geografis (Sig) Untuk Pemetaan Imbuhan Airtanah dan Kerentanan Airtanah di Kawasan Karst (Studi Kasus di Kecamatan Paliyan Dan Kecamatan Saptosari, Kabupaten Gunungkidul). Prosiding Seminar Nasional Aplikasi Teknologi Informasi. Yogyakarta: Universitas Islam Indonesia.

Cahyadi, A.; Hartono, M.B. dan Prabawa, B.A. 2012a. Keterbatasan dan Kendala-kendala Aplikasi Metode APLIS dalam Pemetaan Kerentanan

Airtanah Kawasan Karst di Indonesia. Prosiding Seminar Nasional Geospatial Day. Surakarta: Universitas Sebelas Maret.

Cahyadi, A.; Marfai, M.A.; Nucifera, F. dan Rahmadana, A. 2012b.

Perencanaan Penggunaan Lahan di Kawasan Karst Berbasis Kemampuan Lahan dan Pemetaan Kawasan Lindung Sumberdaya Air: Studi Kasus di Kecamatan Ponjong, Kabupaten Gunungkidul, D.I. Yogyakarta. Prosiding Seminar Nasional Science, Engineering and Technology. Malang: Program Magister dan Doktor Fakultas Teknik Universitas Brawijaya.

Cahyadi, A. dan Priadmodjo. 2012. Pengaruh Penambangan Gamping Terhadap Fungsi Penyerapan Karbondioksida $\left(\mathrm{CO}_{2}\right)$ Atmosfer di Kawasan Karst Kecamatan Ponjong, Kabupaten Gunungkidul. Prosiding 
Seminar Nasional Geospatial Day. Surakarta: Universitas Sebelas Maret.

Cahyadi, A.; Ayuningtyas, E.A. dan Prabawa, B.A. 2013a. Urgensi Pengelolaan Sanitasi dalam Upaya Konservasi Sumberdaya Air di Kawasan Karst Gunungsewu Kabupaten Gunungkidul. Indonesian Journal of Conservation, 2(1): 23-32.

Cahyadi, A.; Pratiwi. E.S. dan Fatchurohman, H. 2013b. Metode-metode Identifikasi Karakteristik Daerah Tangkapan Air Sungai Bawah Tanah dan Mata Air Kawasan Karst: Suatu Tinjauan. dalam Marfai, M.A. dan Widyastuti, M. 2013. Pengelolaan Lingkungan Zamrud Khatulistiwa. Yogyakarta: Pintal. Hal: $50-61$.

Cahyadi, A. 2014a. Keunikan Hidrologi Kawasan Karst: Suatu Tinjauan. dalam Cahyadi, A.; Prabawa, B.A.; Tivianton, T.A. dan Nugraha, H. 2014. Ekologi Lingkungan Kawasan Karst Indonesia: Mejaga Asa Kelestarian Kawasan Karst Indonesia, Edisi 2. Yogyakarta: Deepublish. Hal: 1 - 13.

Cahyadi, A. 2014. Sumberdaya Lahan Kawasan Karst Gunungsewu. dalam Cahyadi, A.; Prabawa, B.A.; Tivianton, T.A. dan Nugraha, H. 2014. Ekologi Lingkungan Kawasan Karst Indonesia: Mejaga Asa Kelestarian Kawasan Karst Indonesia, Edisi 2. Yogyakarta: Deepublish. Hal: $102-$ 113.

Ford, D.C. dan P.W. William. 2007. Karst Geomorphology and Hydrology. Chicester : John Willey and Sons.

Forti, P. 2002. Speleology in The Third Millenium: Achievements and Challenges. Theoritical and Applied Karstology, 15: 7 - 26.

Junbing, P. dan Qian, L. 2012. Environmental Change and Sustainability in Karst System. Guilin: International Research Center on Karst, UNESCO.

Leibundgut, C.; Gunn, J. dan Dassargues, A. 1998. Karst Hydrology. Wallingford, United Kingdom: International Association of Hydrological Science Press.

Radulovic, M.; Stevanovic, Z. dan Radulovic, M. 2012. A New Approach in Assessing Recharge of Highly Karstified Terrains-Montenegro Case Study. Environmental Earth Sciences, 65: 2221 - 2230.

Ravbar, N. 2007. The Protection of Karst Water. Postojna: ZRC Publishing. White, W.B.; Culver, D.C.; Herman, J.S.; Kane, T.C. dan Mylroie, J.E. 1995. Karst Land. American Scientist, 83: 450 - 459.

Williams, P.W. 1993. Environmental Change and Human Impact on Karst Terrains: An Introduction. Catena Supplement, 25: 1 - 19.

Zhen, T.; QuanZhou, G.; ZhenGang, W.; ShengHua, Z.; ChenJi, X.;

PeiSong, L.; XiaoBing, R.; ShuHong, L. dan Hairuo, M. 2011. Estimation 
of Carbon Sinks in Chemical Weathering in a Humid Subtropical Mountanious Basin. Chinese Science Bulletin, 56: 3774 - 3782.

Makalah ini merupakan bagian dari Buku Seri Bunga Rampai dengan Judul "Hidrologi dan Kepariwisataan Kawasan karst Goa Pindul Kabupaten Gunungkidul" dengan Editor Slamet Suprayogi, Setyawan Purnama, Ahmad Cahyadi, Hendy Fatchurohman. Buku ini diterbitkan oleh Badan Penerbit Fakultas Geografi (BPFG) Universitas Gadjah Mada di Yogyakarta Tahun 2016. Makalah ini termuat dalam Halaman 10-17. 